\title{
SIMULATION OF TRAFFIC-RELATED AEROSOL DISPERSION
}

\section{V. Špakauskas and D. Melichov}

Vilnius Gediminas Technical University, Sauletekio 11, LT-10223 Vilhius, Lithuania E-mail: valdas.spakauskas@vgtu.lt

Received 27 October 2011; revised 28 February 2012; accepted 1 March 2012

This paper presents a quasi-empirical model of the distribution of pollutant particles along the roadway. By modelling the source of the pollutant as a cut-off cylinder we assume that aerosol particles (of 0.3-15 $\mu \mathrm{m}$ in diameter) are distributed according to the Gaussian law both along the vertical and horizontal axes. A cross wind translates the pollutant cloud away from the road and the particles are being influenced by gravity, particle buoyancy and thermal plume rise effects. The obtained pollutant concentration function coincides well with the experimental data obtained by Zhu et al. (2011), Grigalavičienè and Rutkovienè (2006), and Zechmeister et al. (2005).

Keywords: aerosol particles, Gaussian distribution, modelling, road dust, dispersion, roadside

PACS: 92.60.Sz, 91.62.Rt, 92.60.Mt, 91.67.gp

\section{Introduction}

The sources of heavy metal pollution are various, for example $\mathrm{Pb}$ from leaded gasoline, $\mathrm{Cu}, \mathrm{Zn}$ and $\mathrm{Cd}$ from car components, tire abrasion, lubricants, industrial and incinerator emissions, etc. [1, 2]. The source of $\mathrm{Ni}$ and $\mathrm{Cr}$ in street dust is believed to be the corrosion of cars [3, 4], and $\mathrm{Cr}$ and Pt of some motor vehicle parts [5]. Moreover, some sort of gasoline contain $30-120 \mathrm{ng} \mathrm{g}^{-1}$ of As [6] and $0.2-3.3 \mathrm{ng} \mathrm{g}^{-1}$ of Hg [7]. Traffic and roads are one of the largest sources of metal pollution, because the number of vehicles in developing countries has been progressively increasing in recent years.

The trace metals near the roadways are transported as particulate matter (PM) $(r>0.1 \mu \mathrm{m}$ in diameter). The mean mass median aerodynamic diamete (MMAD) of PM was found to be $0.85 \pm 0.71 \mu \mathrm{m}$. The MMADs of Pb $(0.96 \pm 0.71 \mu \mathrm{m})$, Cd $(1.14 \pm 0.82 \mu \mathrm{m})$ $\mathrm{V}(1.38 \pm 0.63 \mu \mathrm{m}), \mathrm{Fe}(3.82 \pm 0.88 \mu \mathrm{m})$ [8] can be used to evaluate the concentration of various metal aerosol particles near the roadway. Pollution by heavy metal exists in all countries and is characterised by different ranges of concentration $\left(\mu \mathrm{g} \mathrm{g}^{-1}\right)$ in street dust [9].
Atmospheric dispersion modelling employs statistical tools such as artificial networks (ANN) [10], fuzzy logic theory (FLT) [11], deterministic Lagrangian and Eulerian models [11-14] and so on. But Gaussian type models based on a Gaussian disribution of the plume are most widely used, despite the difficulties in determining the variance $[15,16$. Computational fluid dynamics (CFD) model are used as a tool to assess urban air quality [17 18]. They are based on solving the Navier-Stokes equation, which is completed by finite difference and finite volume methods. Rao et al. [19] showed a significant role of turbulent kinetic energy in dispersion of aerosols.

In the studies of the dispersion of aerosol par ticles from a road, there were proposed various modifications of the Gaussian models in which the road was considered to be either a linear source, a set of point sources, or a planar source with a specfied height. By modelling the dispersion of fine aerosol particles near a road it must be taken into account that these particles are affected by gravitation, particle buoyancy and thermal pollutan plume rise effects and are not uniformly distributed. A good agreement between the model and experimental results, taking into account the aforementioned effects, was obtained by Martinenas and Špakauskas [20].

The results of studies of the vertical aerosol particles dispersion near the ground level [21-23] emphasise the increasing concentrations of $\mathrm{PM}_{10^{2}}$ $\mathrm{PM}_{2.5}$ and $\mathrm{CO}$. Weber et al. [24] evaluated the vertical distribution of particle fractions $\mathrm{PM}_{1}$ and $\mathrm{PM}_{2}$ under different meteorological conditions and found that for up to 3.9 metres the concentration f of aerosol partcles was increasing. The dispersion measurements of ultrafine, fine and coarse aerosol
particles $\left(\mathrm{PM}_{0,3}, \mathrm{PM}_{1}\right.$ and $\left.\mathrm{PM}_{25}\right)$ in an urban particles $\left(\mathrm{PM}_{0.03-0.3}, \mathrm{PM}_{1}\right.$ and $\left.\mathrm{PM}_{2.2}\right)$ in an urban
street canyon [25] show that their concentration increases up to 2.25 metres.

A number of experiments show that the wake of vehicles has a certain structure and this may have significant effect on the dispersion of vehicle pollutants. The wind-tunnel studies of exhaust gas dispersion behind a single vehicle [26] and a queue of vehicles [27] show that concentration contours in cross-section are the optimal fit of the Gaussian distribution. The characterisations of aerosol particles in a dust whirl near the road with accurate measurements have been a key interest in aerosol research for the last several decades. Therefore, in this paper we will investigate the characteristic of heavy metal aerosol particles distribution from roads using a physical model of volume source of pollution in which the pollutants above the road paussian law in both vertical and horizontal directions.

The observed profiles of concentrations of aero sol particles on the road in idle conditions [28] or near the road [29] could be simulated using Gaussian models. Nowadays more and more experiments investigate the vertical concentration profiles near he road. Zhu and Hinds [30] measured the verti(1) Zhis cal profiles of aerosol particle concentrations 50 me-
tres downwind from the roadway and found that tres downwind from the roadway and found that
the maximum concentration of the pollutant was the maximum concentration of the pollutant was observed at a height of 5 metres above the ground. Gillies et al. [31] measured that the size of a wake created by a vehicle depends on the size of that vehicle, i. e. the turbulent wake height $h_{0}$ equals 1.7 multiplied by vehicle height. Based on the results of these measurements the authors obtained the vertical turbulence parameters.

The aim of this work is to develop a model in which aerosol particles over the road would have
Gaussian distribution in the horizontal direction and a truncated Gaussian distribution in the vertical direction and to examine the concentran function of the settled aerosol particles.

\section{Modelling}

We are proposing a quasi-empirical model of setting aerosol particles which are mainly larger than . When there is no wind, the cylindrical whirl of aerosol particles formed by the vehicle-induced mechanical and thermal turbulence gets a cut-off elliptic cylindrical shape. The width $R$ of the cut-off cylinder equals half of the roadway width, and the height of this cylinder is $h$ (Fig. 1). A cross wind translates the wake away from the road with the speed $v_{x}$ and is directed perpendicularly to the roadway, concurrently the cloud of aerosol particles settles at a constant velocity $v_{z}$.

The particles are not uniformly distributed within the cloud. We assume that the distribution along the $x$ axis, where $x$ is perpendicular to the roadway and coincides with the direction of the wind, is

$$
f\left(x, x_{0}-R, \sigma_{x}\right)=\frac{1}{\sqrt{2 \pi} \sigma_{x}} \mathrm{e}^{-\frac{\left(x-\left(x_{0}-R\right)\right)^{2}}{2 \sigma_{x}^{2}}},
$$

where $f\left(x, x_{0}-R, \sigma\right)$ is the probability density, $\sigma$ is the horizontal Gaussian dispersion parameter, $x_{0}$ is the point at which the concentration of aerosols is evaluated, $2 R$ is the diameter of the cut-off cylinder (which is greater than the width of the roadway due o the wake expansion effect).

Consequently, in this paper the truncated Gaussan distribution is suggested to model the distribution of the particles along the $z$ axis, where $z$ is the height above the ground:

$$
f\left(z, z_{0}, \sigma_{z}\right)=\frac{1}{\sqrt{2 \pi} \sigma_{z} \Phi\left(z_{0} / \sigma_{z}\right)} \mathrm{e}^{-\frac{\left(z-z_{0}\right)^{2}}{2 \sigma_{z}^{2}}},
$$

where $f(z, z, \sigma)$ is the probability density function $\Phi(z / \sigma)$ is the cumulative distribution function of the standard Gaussian random variable, $z_{0}$ is the maximum of the probability distribution densit function of the particles, $\sigma_{z}$ is the vertical Gaussian dispersion parameter. 


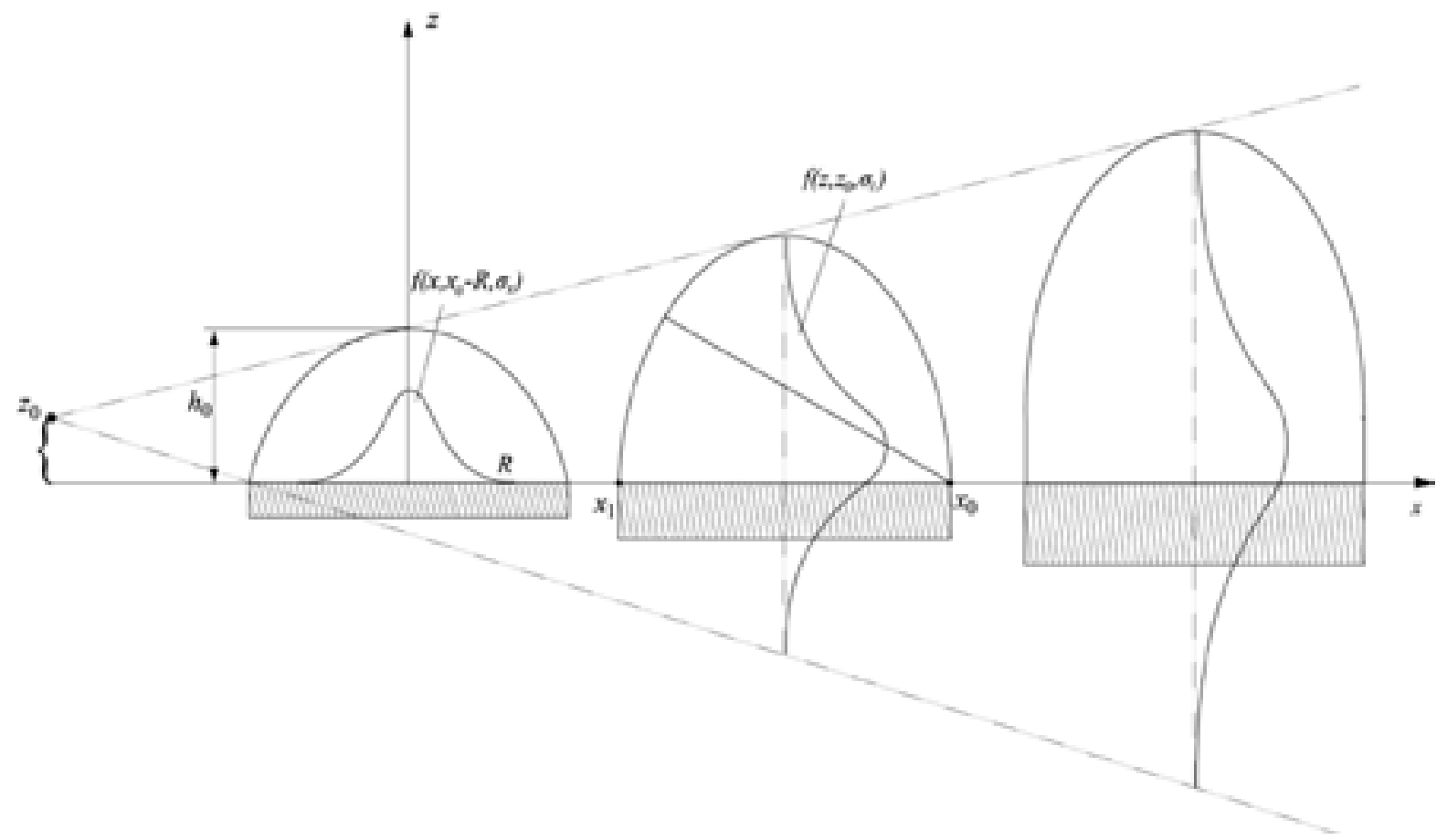

Fig. 1. Settling of the pollutant cloud on the ground surface.

The settling of aerosols carried by the wind is length of the line $z=m(x-x)$ which intersects with modelled by a moving cut-off cylinder of unitary the $x$ axis at the point $x_{0}$ and has the slope $m$. In this length $l=1(\mathrm{~m})$. Suppose that when the centre of case, the concentration of particles at the point $x_{0}$ is this cylinder is at the point $x_{0}-R$, the average density of the particles is

$$
n\left(x_{0}\right)=\frac{N}{V\left(x_{0}\right)}=\frac{N}{\frac{1}{2} \pi R l\left(h_{0}+m x_{0}+\beta x_{0}\right)},
$$

$$
c\left(x_{0}\right)=\int_{x_{1}}^{x_{0}} n\left(x_{0}\right) f\left(x, x_{0}-R, \sigma_{x}\right) f\left(z, z_{0}, \sigma_{z}\right) \mathrm{d} x,(5)
$$

where $x_{1}$ and $x_{0}$ are the points where the line $z$ and the cut-off cylinder intersect. Further,

$$
\begin{aligned}
& f\left(x, x_{0}-R, \sigma_{x}\right) f\left(z, z_{0}, \sigma_{z}\right)= \\
& \frac{1}{2 \pi \sigma_{x} \sigma_{z} \Phi\left(z_{0} / \sigma_{z}\right)} \mathrm{e}^{\frac{\left(x-\left(x_{0}-R\right)^{2}\right)}{2 \sigma_{x}^{2}}} \mathrm{e}^{-\frac{\left.\left(z-z_{0}\right)^{2}\right)}{2 \sigma_{z}^{2}}} .
\end{aligned}
$$

whe volume of the cloud when the centre of the cylinder is at $x_{0}-R, N$ is the total number of aerosols in the cloud, $m=v_{z} / v_{x}, \beta$ is the parameter describing the expansion of turbulent flow.

The cloud carried by the wind at the distance $x_{0}$ shifts downwards at $\Delta h$ :

$$
\Delta h=v_{z} \frac{\Delta x_{0}}{v_{x}}=m \Delta x_{0} .
$$
notin

The movement of particles is influenced by two main factors, namely the settlement and the chaotic movement due to the turbulence effects. In this paper it is assumed that the regular settlement factor is dominant, and on the average the amount of particles settled at the point $x_{0}$ is proportional to the

$$
\begin{aligned}
& c\left(x_{0}\right)=\frac{1}{2 \pi \sigma_{x} \sigma_{z} \Phi\left(z_{0} / \sigma_{z}\right)} \frac{N}{\frac{1}{2} \pi R l\left(h_{0}+m x_{0}+\beta x_{0}\right)} \\
& \mathrm{x} \mathrm{e}^{-\frac{\left(z_{0}-m R\right)^{2}}{2\left(m^{2} \sigma_{x}^{2}+\sigma_{z}^{2}\right)} \int_{x_{1}}^{x_{0}} \mathrm{e}^{-a\left(x-\frac{b}{a}\right)^{2}} \mathrm{~d} x .}
\end{aligned}
$$$$
\left(x_{0}\right)=\operatorname{erf}\left(\frac{2 x_{0}-R}{\sqrt{2} R}\right)-\operatorname{erf}\left(\frac{2 x_{0}-3 R}{\sqrt{2} R}\right)
$$

The Gaussian distribution is always connected with turbulent transport and hence continuous growing of the plume, because of the assumptions that $\sigma_{z}=h_{0}+\beta x_{0}[30]$ and $\sigma_{x}=R$. Therefore, the concentration function can be written as

$$
\begin{aligned}
& c\left(x_{0}\right)=\frac{N}{\sqrt{2 \pi^{3}} R l \sigma_{z} \Phi\left(z_{0} / \sigma_{z}\right)\left(\sigma_{z}+m x_{0}\right)} \\
& \mathrm{xe}^{-\frac{\left(z_{0}-m R\right)^{2}}{2\left(m^{2} R^{2}+\sigma_{z}^{2}\right)}} \zeta\left(x_{0}, x_{1}, a, b\right),
\end{aligned}
$$

(8) The method and formulas presented above allow evaluating the concentration of aerosol particles near the roadway.

\section{Results and discussion}

For the validation of the model developed in our study we use the experimental data obtained by Zhu et al. [32]. In their experiment an optical particle counter with an expected error $\pm 10 \%$ was em ployed to evaluate the distributions of concentrations of differently sized aerosol particles at certain distances from the roadway. Aerosol particle con-

(9) centrations and size distributions in the ranges of

$0.3-0.5,0.5-0.7,0.7-1,1-2.5,2.5-5,5-10,10-15$,
$>15 \mu \mathrm{m}$ were measured at the distances of 5,30 and where

$$
\begin{aligned}
& \zeta\left(x_{0}, x_{1}, a, b\right)=\operatorname{erf}\left(x_{0} \sqrt{a}-\frac{b}{\sqrt{a}}\right) \\
& -\operatorname{erf}\left(x_{1} \sqrt{a}-\frac{b}{\sqrt{a}}\right) .
\end{aligned}
$$

Further, since the value of $m \sigma$ is much smaller than the value of $\sigma_{z}=h_{0}+\beta x_{0}$ and $x_{1}$ can be approximated as $x_{1}=x_{0}-2 R$, the function $\zeta\left(x_{0}, x_{1}, a, b\right)$ can be approximately computed as $>15 \mu \mathrm{m}$ were measured at the distances of 5, 30 and
$100 \mathrm{~m}$ downwind from the central line of a $30 \mathrm{me}-$ $100 \mathrm{~m}$ downwind from the central line of a $30 \mathrm{me}-$
tre wide roadway, when the crosswind velocity varied from 0.5 to $2.3 \mathrm{~m} / \mathrm{s}$ [32].

The model and experimental [32] curves for the size range $10-15 \mu \mathrm{m}$ were normalised at the distance of 30 metres. When wind speed is $v=2 \mathrm{~m} / \mathrm{s}$ they are comparable with one another (Fig. 2). The study found that the shape of the functional dependence of the concentration of aerosol par ticles on the distance from the roadway is mainly

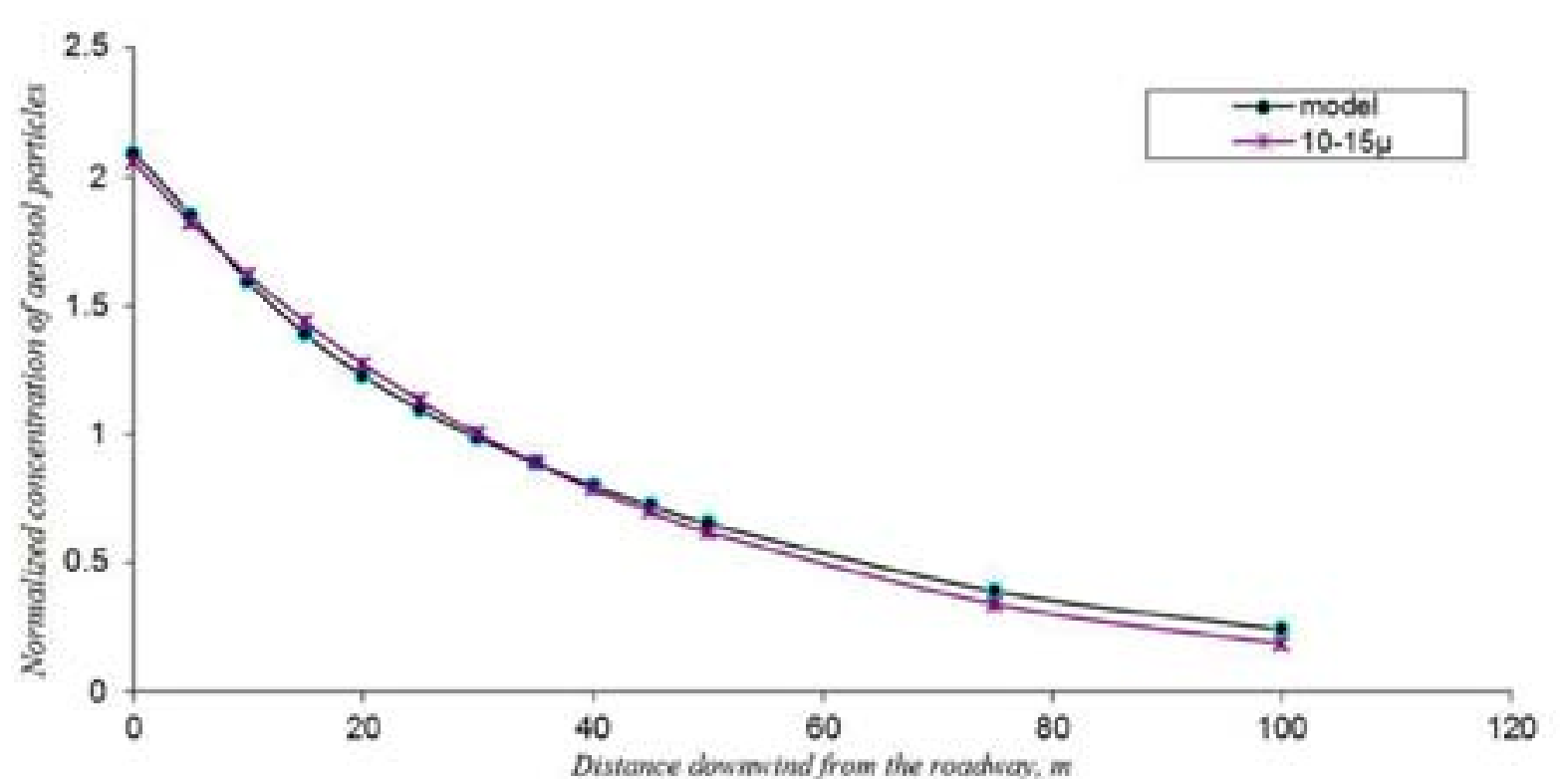

Fig. 2. Comparison of the normalised experimental (Zhu et al. 2011 [32]) and current work model dependence of aerosol particle concentrations on the distance from the roadway when wind speed is $2 \mathrm{~m} / \mathrm{s}$. 
determined by the parameters $m$ and $\beta$. The dependence on $m$ can be explained by the fact that for up to $50 \mathrm{~m}$ from the road the turbulence effects are dominating; therefore, all the particles are uniformly mixed. The parameter $\beta$ describes the expansion of the turbulent wake of the vehicle flow and $\beta=0.044+0.004 d$, where $d$ is the diamete of aerosol particles. When wind speed is different from that considered by Zhu et al. [32] the expression of $\beta$ should also change, but this requires additional measurements.

\section{Conclusions}

The distribution of traffic-related aerosol particle on the roadside has been investigated using the developed model of volume source above the road. The pollution source is treated as a cut-off elliptic cylinder which is formed on the roadway at the nitial time moment due to the traffic pollution and filled with aerosol particles which are distributed according to the Gaussian law in both vertical and horizontal directions. A semi-empirical model has been proposed for the simulation of dispersion of particles with the diameter larger than $0.3 \mu \mathrm{m}$ near roadways. The modelled data agree with the experimentally measured dispersions of aerosol particles. The determined dispersion curves depend on the parameters $m$, describing sedimentation, and on $\beta$, which characterises the wake of vehicle flow. Since the obtained tion of the aerosol particles coincides well with the experimental data provided by Zhu et al. [32] and the shape of its functional dependence on the distance from the roadway agrees with the results of $[33,34]$ we assume that the proposed model can be successfully used to model the dispersion of aerosol particles near roadways.

\section{References}

[1] J.A. Markus and A.B. McBratney, An urban soil study: heavy metals in Glebe, Australia, Aust. J. study: heavy metals in Glebe,
Soil Res. 34, 453-465 (1996).

[2] W. Wilcke, S. Muller, N. Kanchanakool, and W. Zech, Urban soil contamination in Bangkok: W. Zech, Un and aluminium portioning in topsoils, Geoderma 86, 211-228 (1998).

[3] J.E. Ferguson and N. Kim, Trace elements in stree and house dusts source and speciation, Sci. Tota Environ. 100, 125-150 (1991).
[4] M.S. Akhter and I.M. Madany, Heavy metal in street and house dust in

[5] S.M. Al-Shayeb and M.R.D. Seaward, Heavy meta content of roadside soils along ring road in Riyad (Saudi Arabia), Asian J. Chem. 13, 407-423 (2001).

6] Y. Nakamoto, Rapid determination of arsenic in thermally cracked gasoline by graphite-furnace AAS, Bunseki Kagaku 49, 43-47 (2000) [in Japanese].

[7] L. Liang, M. Horvat, and P. Danilchik, A nove analytical method for determination of picogram levels of total mercury in gasoline and other petroleum products, Sci. Total Environ. 187, 57-6 (1996)

[8] C. Samara and D. Vousta, Size distribution of airborne particulate matter and associated heavy metals in the roadside environment, Chemosphere 59(8), 1197-1206 (2005).

[9] A. Christoforidis and N. Stamatis, Heavy metal contamination in street dust and roadside sol along the major national road in Kavala's region Greece, Geoderma 151, 257-263 (2009).

10]D. Podnar, D. Koračin, and A. Panorska, Application of artificial neural networks to modeling the transport and dispersijon of tracers in complex terrain, Atmos. Environ. 36(3), 561-570
(2002).

1]B. Fisher, Fuzzy environmental decision-making: application to air pollution, Atmos. Environ

2]D. Oettl, J. Kukkonen, R.A. Almbauer, P.J. Sturm M. Pohjola, and $J$. Harkonen, Evaluation of data set, with emphasis on low wind speed condi(ions Atmos. Environ. 35(12) 2123-2132 (2001). 13]S. S. Rasa, R. Avila and J. Cervantes, A 3-D

Jaranan tmospheric dispersion applications. Des. 208(1), 15-28, (2001).

14] A.G. Clarke, L.A. Robertson, R.S. Hamilton, an B. Gorbunov, A Lagrangian model of the evolution of the particulate size distribution of vehicula emissions, Sci. Total Environ. 334-335, 197-206 (2004).

[15]F. Pasquill, The estimation of the dispersion of windborne material, Meteorol. Mag. 90, 33-49 (1961)

[16] Jr.F.A. Gifford, Consequences of effluent releases Nucl. Safety 17(1), 68-86 (1976).

[17]P. Neofytou, A.G. Venetsanos, S. Rafailidis, and J.G. Bartzis, Numerical investigation of the pollution dispersion in an urban street canyon, Environ. Model. Software 21, 525-532 (2006).

[18] D.R. Parsons, G.F.S. Wiggs, I.J. Walker, R.I Ferguson, and B.G. Garvey, Numerical modelling of airflow over an idealised transverse dune, Environ. Model. Software 19, 153-162 (2004).
[19] K.S. Rao, R.L. Gunter, J.R. White, and R.P. Hosker, Turbulence and dispersion modeling near highways, Atmos. Environ. 36, 4337-4346 (2002).

[20]B. Martinènas and V. Špakauskas, Simulation of traffic pollution dispersion near roadways, Lith. J. Phys. 50(2), 255-260 (2010).

[21]A. Micallef and J.J. Colls, Variation in airborne particulate matter concentration over the first three metres from ground in an urban street canyon: implication for human exposure, Atmos. Environ. 32(21), 3795-3799 (1998)

[22]J.J. Colls and A. Micallef, Measured and modelled concentrations and vertical profiles of airborn particulate matter within the boundary layer of street canyon, Sci. Total Environ. 234, 221-233 1999

[23]S.-K. Park, S.-D. Kim, and H. Lee, Dispersion characteristics of vehicle emission in urban street canyon, Sci. Total Environ. 233, 263-271 (2004).

[24]S. Weber, W. Kuttler, and K. Weber, Flow charac teristics and particle mass and number concentration variability within a busy urban street canyon Atmos. Environ. 40, 7565-7578 (2006)

[25]P. Kumar, P. Fennell, D. Langley, and R. Britter Pseudo-simultaneous measurements for the vertical variation of coarse, fine and ultrafine particles in an urban street canyon, Atmos. Environ. 42, $4304-4319$ (2008).

Tera, Y. Yamao, Y. Yoshikawa and T. Morikawa, A wind-tunnel study on exVelocity dispersion from road vehicles-Part 1

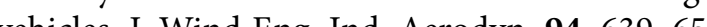
(2006).

\section{TRANSPORTO SUKELTU AEROZOLIỤ DALELIU SKLAIDOS MODELIAVIMAS}

\author{
V. Špakauskas, D. Melichov
}

Vilniaus Gedimino technikos universitetas, Vilnius, Lietuva

Darbe pasiülytas kvaziempirinis modelis, skirtas didesnio kaip $0,3 \mu \mathrm{m}$ skersmens daleliu sklaidai pakelese modeliuoti. Modeliuojant taršos šaltinị kaip nupjautin cilindrą laikome, kad aerozolių daleles $(0,3-15 \mu \mathrm{m}$ diametro) taršos šaltinyje vertikalia ir horizontalia kryptimis pasiskirsto pagal Gauso dèsnị. Pučiant vèjui, kurio
[27]I. Kanda, K. Uehara, Y. Yamao, Y. Yoshikawa, and gas dispersion from road vehicles-Part II: Effect of vehicle queues, J. Wind Eng. Ind. Aerodyn. 94 659-673 (2006).

[28]Z. Ning, C.S. Cheung, Y. Lu, M.A. Liu, and W.T. Hung, Experimental and numerical study of We (2) Environ. 39(40), 7880 (2005).

Y. Zhu and W.C. Hinds, Predicting particle number concentrations near a highway based on ver1557-1566 (2005)

[31]J.A. Gillies, V. Etyemezian, H. Kuhns, D. Nikolic and D.A. Gillette, Effect of vehicle characteristic on unpaved road dust emissions, Atmos. Environ

A.W. Ge.D. Kuhns, J.A. Gilies, V. Etyemezian, velocities from changes in, Inferring deposition A.W. Gestributions downwind

[33]I. Grigalavičienè and V. Rutkovienè, Heavy metals accumulation in the forest soils and mosses along 12-19 (2006).

A. Zechmeister, D. Hohenwallner, A. Riss, an derived filnar, Estimation of element depositio

kryptis statmena keliui, dulkių debesis yra nešamas tolyn nuo kelio, o aerozolio daleles yra veikiamos gravitacijos, dalelių plüdrumo ir terminio teršalu fakelo kilimo efektul. Gauta teršalu koncentracijos kaita transporto magistralès salikelèse sutampa su eksperimentiniais matavimais (Zhu ir kt., 2011; Grigalavicienè ir Rutkoviene, 2006; Zechmeister ir kt., 2005). Environ. 16(6), 1399-1405 (1982). 